\title{
Futures Studies of Political Currents in Islamic Republic of Iran
}

\author{
Maliheh Ramezani
}

\author{
Seyed Javad Emamjomezadeh
}

Seyed Amirmasod Shahramnia

\section{Mohammad Rahim Eivazi}

Department of political sciences, University of Isfahan, Isfahan, Iran

\author{
Doi:10.5901/mjss.2016.v7n6p233
}

\begin{abstract}
The political currents available in every political system play essential role in the history and evolution of societies. Therefore, knowing the current and future state and the factors affecting them is very important. Futures studies is the knowledge of analyzing, designing and forming of the future. Considering the spread of future studies and its comprehensive application in various political-social aspects of human's life, this article aims to investigate the main driving forces which forming Iran's political currents. This study applies an analytical-descriptive method following a futurical approach for analyzing the most important factors and driving forces that form the political currents in Iran. First, the Futures studies and Iran's political currents are explored. Then by analyzing the driving forces influenced political currents, the importance and uncertainty of the factors are examined using a survey. This survey asks for experts' views on the issue. Finally, by analyzing different views, the article tried to identify the main uncertainties in Iran's political currents which are of importance in future changes.
\end{abstract}

Keywords: Futures Studies, Driving forces, uncertainty, Political currents, Islamic Republic of Iran

\section{Introduction}

The life's condition of modern human has some features such as uncertainty, complexity, and hasty changes which govern decision and policy making. The same condition exists in the political currents which force to attention as possible as to this domain. Dealing successfully and desirably with the new situations requires new tools which include Futures studies as one of the most favorable. In fact, Futures studies is one of the new fields in the of human studies which is attended extensively despite its novelty. Nowadays Futures studies is appearing largely in the scientific realms and is establishing a strategic research basis.

Knowing the current and future state of the political currents has the great importance. In fact, consequences of the political life of every society arise from how the political currents interact and change which form the basis for decisions and actions taken to enjoy a political system survival. In fact in the field of political sociology, the political movements are considered one of the strong powers in formation of political-social changes and it shows its increasing necessity. This state can be observed in all societies that in developing countries investigating this subject is of high importance. The victory of Islamic revolution in Iran has also caused major changes in its political currents which includes removal and marginization of some currents versus the increased importance of the others. Exploring future of the political currents, especially main factors forming them is very important regarding various changes taken place due to communication and technology developments and the regions' happenings. This study is to find answers to the main questions according to the mentioned points: what are the main driving forces affecting rise of Iran's political currents? Accordingly, this work tries to identify main uncertainties in Iran's political currents by using uncertainty matrix. To fulfill the aim of the study, the most important drivers and actors will be explored applying experts' views based on features like importance and predictability. The results obtained will be used to gain a true understanding of the main factors and features shaping future of the political currents which are vital in applying techniques and strategies in this domain.

\section{Research Method}

Futures studies includes the concept of "looking ahead to future". In Wendell Bell's view, the Futurist is seeking a 
systematic study in which he could discover, invent, present, test and evaluate possible, probable and preferable futures. Futurist is always facing a range of futures which can be effective in knowing the future. The issues included in Futures studies domain are "possible", "probable", and "preferable" futures for transforming from present to future. In Bell's opinion, futurists are seeking to find: 1 . what are the things which can or could be possible, including all the futures which can be imagined no matter if they are not achievable (possible future). 2. How probable are they (probable future); it is possible to consider the probability of these futures for some are more probable than others. 3 . What actions have to be taken (preferable future) (Bell, 2003:73).

The present study enjoys an analytical descriptive approach which aims to investigate the future in the domain of political sociology. This study due to its Futures studies nature does not follow hypothesis testing strategy. Applying qualitative materials and methods, this work has a qualitative nature too. To investigate the issue and identify the key uncertainties and drivers affecting Iran's political currents, uncertainty matrix is applied. Generally there are various ways to investigate the future and effective factors on it. Causal layered analysis method, morphology analysis, the method of decreasing background maladaptation, procedure analysis, uncertainty matrix, etc. each one of the above methods addresses the future and its changes in a way. Considering the complexity of the field of political movements and being under the effect of the elements and different factors, the uncertainties matrix has been used in the present paper, since it has application in investigating and identifying propeller powers forming the future. The extent of future changes and outcomes unpredictability is called uncertainty. For example, in a company the future behavior of the competitors is highly uncertain, while the demographic trends are less uncertain. The uncertainties refer to those factors which are unknown regarding their results (Rokoie, 2015:34). Since effective factors on political movements in the field of political sociology and investigating changes made in them are not the same in all societies and they are under the effect of the present condition and elements in that societies, in the current paper it was attempted to address the investigation of these factors and elements in the field of political movements in Iran, of course this investigation is considered as a general basis to investigate the political movements of other societies too.

\section{Classification of Political Currents in Islamic Republic of Iran}

Literally, current means "flowing" and "happening". Current is a group of actions, events and thoughts to achieve certain goals (Dehkhoda, 2006: 869). When a group of people, having special common thoughts, principles and ideas gather and start a collective action and social, cultural, economical political movement, a social cultural, economical political current will be created. Knowing the currents includes system identification, thought formation and transferring a thought into an organization and movement, studying the evolution process from the formation time to prosperity, productivity, maturity, recruiting, interactions and exchanges with other currents (Khoramshad, 2013: 66). What is understood of current concept in this study consists of a social phenomenon with an intellectual approach. In other words, it is a thought maintaining the principles and criteria required for sociability which is applied to be involved in political-social changes. Knowing the current is to know the principles, rules, directions and approaches governing various social groups in political sociology domain and consequently the changes and evolutions which has happened.

The victory of Islamic revolution in Iran as one of the most important events in Iran's history has caused main changes in different domains. The mentioned changes are also evident in political domain. By eliminating the monarchy from the realm of political-social developments, Iran's main political currents, after Islamic revolution, can be divided into Islamic religious current, left, nationalist, and modernist.

\subsection{Left current (socialist)}

In the first years after victory of Islamic revolution, left current had been consisted of small groups. Lacking a broad social base, they could not create barriers for the other political forces (Khaje Sarvi, 2003: 229). The same reason, lacking a broad social base, influenced greatly on the lack of united strategic force for the left party. After Islamic revolution, the most important groups and organizations forming this current were consisted of: 1. Tude party (party of the masses of Iran); 2. Fadayan-e-Khalgh (a Guerrilla organization devoted to people in Iran) and Mojahideen-e-khalgh party or MEK. Left current was one of the currents after Islamic revolution which tried to play a role in Iran's political structure and decide on its political system but could not play any active role due to some reasons. In fact, due to continuous struggle against monarch regime and Savvak's pressures and lack of public interest into their ideology, they could not play an active role in the process of new political system formation. Despite their attempts to support Irans' Islamic regime, they were arrested by security forces and the scope of their activities was severely restricted in Iran because their thinking principles were in conflict with that of governing religious movement led by Imam Khomeini. 


\subsection{Modernist current}

Modernism was formed from Constitutional era in Iran and mostly followed western secular trends. In Pahlavi II era a new generation of modernist current called religious or local modernism was noticed. The same trend continued after Islamic revolution. So the modernists can be classified in two groups:

\subsubsection{Democratic modernism}

One of the effective currents in the first years of Islamic revolution in Iran was democratic modernism based on liberal principles. This current was seeking to run a democratic government based on religious instructions applying moderate and liberal principles in Iran after revolution. The leader of this current had taken the responsibility of interim government immediately after the victory of revolution.

All the groups forming modernist force have in common the acceptance of western values which were set after revolution in seeking a republic system and realization of parliamentary democracy. They tried to affect the changes process, which led to the formation of political system after the revolution (Khaje Savi, 2003, 228). The conflict between liberal democratic modernists on the one hand and their conflict with the leader of the revolution and revolutionary people on the other hand was getting more and more severe. Treating the issue in a gentle submissive way by the interim government and subsequently prime minister's meeting with Berjinsky brought the conflicts to their climax which ended up in the opening of America's embassy and Bazargan's resignation and the end of interim government (Mohammadi, 2002, 155). Modernist current despite its success in the first years of Islamic revolution in establishing an interim government, due to its conflicts with the principles of religious currents could not turn into an effective current in the domain of social-political changes in Iran. In other words, the nature of Islamic revolution in Iran and the goals of Imam Khomeini and the other religious leaders were so different with that of liberal forces.

\subsubsection{Religious eclectic modernism}

This group of modernists has been to identify the religion position in the process of modernization, or to say differently, the relation between modern science and reason. In fact, this current is seeking to reconcile Islam with the modern age and its conditions. Abdolkarim Sorush and Mohammad Mojtahed Shbestary were two of its important thinkers. Generally, main aspects of this intellectual current include the rejection of religion integrity. Therefore, a restricted scope is considered for religion. Considering this current, religion is provided to give help in cases the reason is unable to understand. So what is expected of this religion is to guide the mankind regarding the hereafter.

Based on their perspective, all the issues in the government are not the legal one that the law is responsible for. Accordingly, the scope of legal acts is limited. They believe that jurisprudence is not a suitable criterion for directing modern society. It is only a rational science to answer the questions of laws and values and it is the reason which is responsible in understanding the religion (Sorosh, 1991, 26). As the result of such an approach, collective reason as one of the basis for understanding the religion becomes important. Contrary to Bazargan, Sorush tried to show how to know the religion applying science in his attempts to reconcile science and Islam or in other words, science and religion, in his political view. Additionally, distinguishing between religion and religious knowledge, he believes that Quaran and the tradition are always constant, but the religious knowledge resulted from them is affected by the possible condition and is subject to change.

\subsection{National religious}

Nationalist current was considered as illegal and its acts were restricted due to the emergence of some conflicts after Islamic revolution of Iran. Gradually some people who were following the principles of nationalism under the leadership of Mossadeq added the title of Islam to this current and introduced a new branch known as national- religious current to continue their actions. In fact national religious current can be considered as one of the modernist branches. These people are part of a wide range who consider themselves as ones continuing Mosadeq's way. The roots of this kind of political activities accompanying maintenance of religious views (Islam, Shiite) can be seen in freedom movement. But after death of Imam Khomeini and at the end of Hashemi Rafsanjani's presidency, this title was gradually used in some publications and newspapers and during the presidency of Mohammad Khatami, a political group called "nationalreligious party" (the council of active nationalist religious people in Iran) were announced. They were trying to define their current position regarding at least two other currents of national and religious. On the same basis this party raised Iranian 
and Islamic claims by proposing superiority of being an Iranian. Thus it can be said that nationalism is one of the new political currents in nationalist currents than occurred after Islamic revolution.

\subsection{Islamic religious current}

Islamic current can be considered as one of the most important political currents that influenced highly on political changes in Iran. Imam Khomeini's opinion was realized by the victory of Islamic revolution and Islamic current turned into a major current in Iran. This current advocated social- political Islam and the attempt to establish an Islamic government in which Islamic laws are implemented in society and Islamic jurists monitor them (Fozi, 2009: 63-63). Considering the scope and organization, Islamic republic party among the other forces was a clear case which was formed at the social level. Tehran Combatant Clergy Society and the Society of Seminary Teachers of Qom organized the spiritual aspect of this force and Mojahedeen Organization of Islamic revolution formed in 1979 held mechanisms of organizational coordination, planning and security guards (Khaje Sarvi, 2003: 225). Therefore, during the years after the victory of Islamic revolution, Islamic current has been one of the major political currents in Iran and has constantly tried to determine its border by expressing its own principles and views and provide theories to solve the crisis and revolutionary condition prevailing in Iran. What can be said regarding this current is that during the years after the victory of Islamic revolution some other currents have been formed that operate as religious ones in spite of their differences.

Islamic current after the victory of Islamic revolution consists of reformism, religious fundamentalism, and party. Religious fundamentalism and moderate party entered political currents in Iran in1370s which have presented before as left and right parties respectively. So, political current has always existed as a social reality which has undergone changes.

\section{The Main Actors Affecting Political Currents in Iran}

In investigating the current political movements in every society, recognizing propeller powers and effective players on them are necessary to investigate their futuristic investigation in order to address planning and decision making suitable for them. The main actors and drivers affecting political currents in Iran are investigated in the following parts. Each driver is designed considering the influence on political currents in Iran and its changes in different political, economical, social and cultural aspects. First, the most important actors in the domain of political currents are mentioned. Then the driver forces in future changes are discussed.

\subsection{Classifying actors based on effective institutions}

"Institution is usually defined as a system of organizations, values, ethnic styles, habits, customs, and rules whose role is to set appropriate behaviors for performing basic functions in society" (Mohseni, 2002: 163). In a more comprehensive definition, institution is "a stable organized system of the social patterns which includes some of the controlled behaviors to meet the social needs." (Cohen, 1979: 51). Due to the significant role of centers of power and political institutions in the processes of development in developing countries, investigating the role of government and mentioned institutions are essential (Azarmand, 2006: 122). The political institutions represent special choices about the formation of political relations. These institutions are of a nature that incite the members constantly to pursue some political goals in specific ways. Political institutions can be considered as ones carrying normative elements (Marsh \& Stooker, 2010: 90). The political institutions included in this article are laws and regulations such as constitutional law, official government institutions and their organs like executive, legislative, and judicial. So, one of the levels affecting political currents in Iran are the institutions. Each of these institutions plays its own role in forming the political currents by adopting general policies in the field of political parties and currents, and determining their activities and so on.

\subsubsection{Major institutions affecting political currents in Iran}

Supreme Leader: One of the most important institutions affecting different aspects of social-political life is the leadership. Based on constitutional law in Islamic republic of Iran, decision making regarding the general policies in the government is within the realm of supreme leader's authority after consulting expediency council (paragraphs 1 and 2, article 110, constitutional law). Policy making includes determining, developing, and providing criteria and standards to meet the government's general requirements and nation's collective interests. (Hashemi, 1366: 49). Article 110 (paragraph 8) also states that one of the supreme leader's responsibilities and powers is to "solve system's problems which is not normally 
solvable by the help of expediency council".

Supreme leader's decisions about political currents are also the guideline in this domain. In other words, supreme leader's role is to discourse upon principles and achievements of Islamic revolution accompanying Imam's ideals in the society. He always tried to repeat discourse of Islamic revolution (interview with Seied Morteza Nabavi). In addition to referring to dos and don'ts in political currents and groups, he always attempted to prevent the influence of the political currents affected by liberal and secular western currents. Facing critical situations like what happened in 1388 in presidential election, supreme leader tries to manage the crisis and avoid divisions and differences in political currents and loss of political stability and cohesion in Iran.

President: There is a close relationship between president and the political currents. During different times after the victory of Islamic revolution, It was notice that the slogans, attitudes, and generally approaches and discourses adopted by each president affected greatly on the political currents. Islamic republic of Iran has formed out of the discourses governing each political era so the changes occurred in the prevailing discourses Iran have crucial role in political currents. Some changes happened in the formulation of the political currents in each era to fit the political prevailing discourse. For example, with the victory of Mohammad Khatami in the election and raising reform discourse, the formation of political currents based on reform and fundamentalism was noticed. Raising moderate discourse in Hasan Rohani's government, the political currents were set as moderation-based. Additionally, a lot of political parties were formed by the presidents. To provide some examples, the executives of construction party and moderation and development party were formed by Hashemi and Rohani respectively (interview with Seyed Morteza Nabavi).

Expediency council: Considering the acts and paragraphs of constitutional law in Islamic republic of Iran, some of the responsibilities of this council are as followes: giving advice to the supreme leader in determining system's general policies (based on paragraph 1, act 110, constitutional law), suggesting solutions for solving problems which seems unsolvable normally (paragraph 8 , act 110), monitoring implementations of the general policies (based on the supreme leader's letter in 17/1/1377) (site of expediency council).

Therefore, the expediency council is a crucial institution regarding policy making and approving system's general policies about parties and existing political currents and creating social-political cohesion in the society. To say in different words, the role of this council has to be examined accompanying the supreme leader's role

Ministry: According to the law, main duties and missions of the ministry which is related to the political currents are consisted of: trying to realize and develop political and social freedoms within the framework of constitutional law and other regulations of the country, providing stable social and political development, promoting public participation, providing the proper ground for desirable actions of the parties and political and non-governmental organizations and monitoring their activities, directing and supporting Islamic councils and monitoring their activities, and planning for elections (Ministry portal). Accordingly, ministry is one of the important institutions in monitoring activities and functions of the political currents. In fact, activities of all the political groups and organizations are examined by the ministry.

Islamic parliament: The main function of Islamic parliament is to pass laws and regulations related to various issues which is also its main role in the political currents.

Judiciary: Constructing legal provisions for the activities of political parties and organizations is performed by this institution.

Guardian council: Guardian council is one of the important institutions in Islamic republic of Iran. This council is responsible for monitoring the elections and is also considered as the main reference for interpreting constitutional law. The guardian council supervises assembly of experts election, presidential and parliamentary elections with recourse to public votes. One of the issues related to the election supervision is to approve the accuracy of the election and candidates' qualification which is one of the essential stages in every election. Paragraph 9, act 110, says:

"Qualification of the candidates for presidential election must be approved by the guardian council before the election in respect of having the conditions mentioned in this act." (guardian council's site). So guardian council's role in the political currents is to let the qualified people into important social-political positions by monitoring the elections.

So, the political institutions can be considered as one of the effective actors in Iran's political currents which include official institutions in various levels.

\subsection{Classifying actors based on influential people}

Different factors influence the process of decision making. One of them is the policy makers or those involved in making decisions in different aspects of political, economical, cultural, etc but they have different views in each aspect. Since decision makers make their decisions regarding their own different perspectives, the decisions made will be different too. Therefore, one of the effective factors in the political currents is the active people in this domain who play their roles on 
the basis of their own social-political attitudes, approaches, and benefits. Different actors have also played important roles in Iran's political currents. Among them the supreme leaders, presidents, presidents of the parliament have had the most important effects on the political currents. This article tried to mention the main policy and decision makers in Iran's social-political system. Table 1 shows these influential people, classifying them in two groups of people with stable intellectual approach and those with intellectual approach lacking consistency.

Table 1: Most important influential people in Iran's political currents

\begin{tabular}{|ll|}
\hline stable & unstable \\
\hline Mirhossein mosavi & Seyed Ali Khamenei \\
\hline Mehdi karobi & Ali akbar hashemi Rafsanjani \\
\hline Mahmood ahmadinejad & Seyed Mohamad Khatami \\
\hline & Hasan Rohani \\
\hline & Nategh Noori \\
\hline & Gholamali Hadad adel \\
\hline & Ali Larijani \\
\hline
\end{tabular}

The people mentioned in the table above have been influential in Iran's political currents. To give an instance, Hassan Rohani, as Iran's president at the top of its political structure, mentioned moderation as his political slogan. If his attempts are met, moderate political current will be developed in the society. Regarding two groups of decision and policy makers with two different intellectual approaches, the dominance of the people belonging to each intellectual approach can change the future of the political currents in Iran.

\section{Drivers of Iran's Political Currents}

In the future studies, drivers refer to the main forces forming the future. Drivers affect different domains indirectly. In other words, the features or the components of several procedures cause the changes in an area under study. In fact, driver forces are the forces which influence on the events consequences and include a concept which is mostly applied in designing scenarios. To say it differently, the features that keep the story of the scenarios on (Schwartz, 1388: 65). There are different ranges of factors which have influence on formation of the political currents. Table 2 represents the main political, social, economical and cultural drivers affecting Iran's political currents.

Table 2: Effective drivers in Iran's political currents

\begin{tabular}{|llll|}
\hline Political & Social & Economic & Cultural \\
\hline The social-political conditions of elections time & National unity and coherence & Resistance economy Interest in foreign culture \\
\hline People's demands & Social stability & Reinter state & Social networks and media \\
\hline Leadership & Ethnic problem & $\begin{array}{l}\text { People's economic } \\
\text { participation }\end{array}$ & Clever cultural approach \\
\hline Active participation of the political characters & Environmental conditions & $\begin{array}{l}\text { Foreign economic } \\
\text { constraints }\end{array}$ \\
\hline Relationship between religion and politics & Social capital & \\
\hline political competition & $\begin{array}{l}\text { Spirtual and mystical tendencies } \\
\text { without respect to Sharia }\end{array}$ & \\
\hline Political crisis & Social corruption & \\
\hline Religious democracy & & \\
\hline
\end{tabular}

As it was mentioned, various features and factors called drivers in different economic, social, cultural and political levels affect Iran's political currents. Since different drivers have different effects, they should be distinguished regarding amount of their influence. More attention should be given to the most effective drivers and an image of the future should be depicted out of them. Apart from the importance of the drivers, their uncertainty must be considered too. Uncertainty means inability to predict and assign probability to the future situation of each driver. So, drivers should be evaluated considering their importance and uncertainty. In fact, the drivers with the most importance and higher level of uncertainty will be applied in forming future of Iran's political currents. 


\subsection{Questionnaire determining the importance and uncertainty of drivers in Iran's political currents}

To determine the importance and uncertainty of the drivers affecting political currents in Iran, a questionnaire was prepared and presented to a group of experts. To assess the importance and uncertainty of the drives a Likert scale of 5 choices were used. The participants were asked to choose their views regarding the importance and uncertainty of the drivers among the scales of 1 (too law), 2 (law), 3 (average), 4 (high), 5 (very high). Four general features level of education, Field of Study, teaching experience and research, and academic rank were used to describe the participants. Graphic representation of these features are represented below:

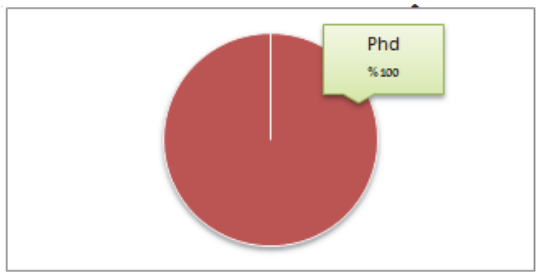

Graph 1: level of education

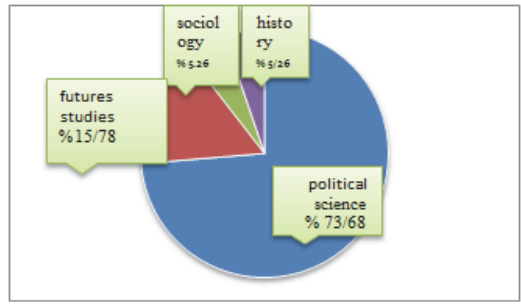

Graph 2: Field of Study

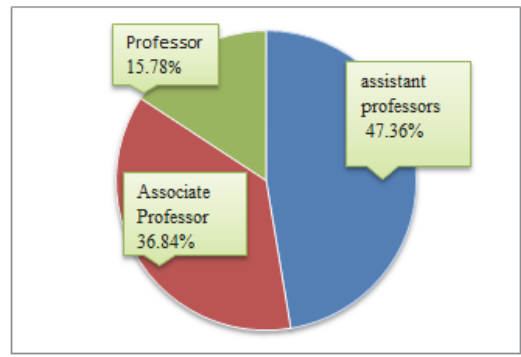

Graph 3: academic rank

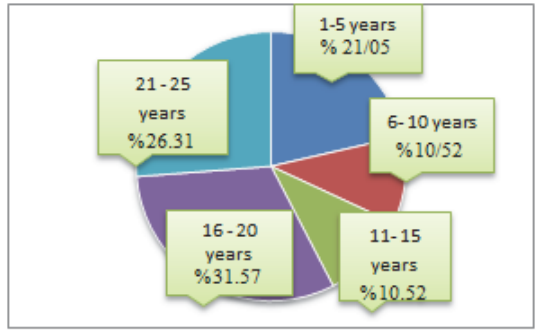

Graph 4: teaching experience and research 
As it was shown in the above graphs, all the participants majored got PHD in political science, futures studies, sociology, and history (graph 1 and 2). Graph 3 shows that the participants were assistant professors. Graph 4 represents teaching and research experiences of the participants. More than 60 percent of the participants had more than 10 years of research and teaching experiences.

\subsection{Analyzing the results of the questionnaire}

The results obtained out of the questionnaire were analyzed to determine the importance and uncertainty of each driver. The results are represented in table 3.

Table 3: Analysis of the importance and uncertainty of drivers in Iran's political currents

\begin{tabular}{|lccc|}
\hline driver & code & importance & uncertainty \\
\hline The social-political conditions of elections time & PS & 4.05 & 2.77 \\
\hline People's demands & DP & 3.77 & 3.88 \\
\hline Leadership & TL & 4.33 & 3.66 \\
\hline Active participation of the political characters & PF & 3.55 & 3.72 \\
\hline Relationship between religion and politics & RP & 3.44 & 3.44 \\
\hline Political competition & CS & 4 & 3.27 \\
\hline Religious democracy & RD & 3.11 & 3.05 \\
\hline Political Participation & PP & 4.27 & 3.05 \\
\hline Political crisis & PB & 3.88 & 2.88 \\
\hline National unity and coherence & US & 3.55 & 2.88 \\
\hline Social stability & PO & 3.61 & 2.88 \\
\hline Ethnic problem & PQ & 3.55 & 2.88 \\
\hline Environmental conditions & EC & 2.77 & 3.61 \\
\hline Social capital & CS & 3.83 & 3.5 \\
\hline Spiritual and mystical tendencies without respect to Sharia & MT & 2.11 & 2.61 \\
\hline Religious extremism & RE & 3.33 & 3.11 \\
\hline Social corruption & SR & 3.61 & 3.5 \\
\hline Resistance economy & ES & 2.66 & 2.88 \\
\hline Reinter state & RS & 2.38 & 3.88 \\
\hline People's economic participation & EP & 3.72 & 3.33 \\
\hline Foreign economic constraints & FE & 3.83 & 3.66 \\
\hline Interest in foreign culture & FC & 2.77 & 3.27 \\
\hline Social networks and media & MS & 4.05 & 3.16 \\
\hline Clever cultural approach & MP & 3.38 & 3.27 \\
\hline
\end{tabular}

Considering the information in table 3, drivers affecting Iran's political currents are represented in the following graph. Drivers for Iran's political currents are classified into five groups of key driver scenarios, important driver scenarios, key issues in planning, important issues in planning, and monitoring.

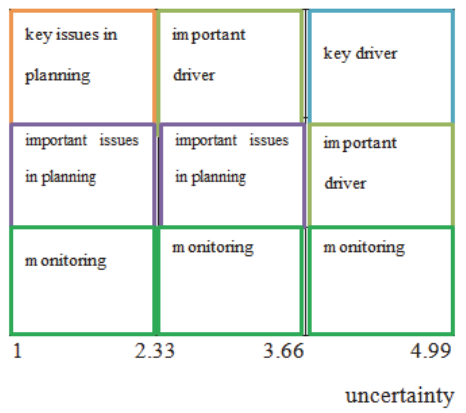


Above table shows that different drivers have different levels of importance and uncertainty which are classified as low (2.33-1), average (3.66-2.33) and high (3.66-4.99). The key drivers and uncertainties are identified reagarding the information gathered in table 4.

Table 4: Drivers position in importance-uncertainty matrix

\begin{tabular}{|c|c|c|}
\hline $\begin{array}{l}\text { key issues in } \\
\text { planning }\end{array}$ & $\begin{array}{l}\text { im portant } \\
\text { drivers } \\
\text { PS, SC, MS, EP, } \\
\text { CS, PP, PB, FE }\end{array}$ & $\begin{array}{r}\text { key drivers } \\
\text { DP } \\
\text { TL }\end{array}$ \\
\hline & $\begin{array}{l}\text { important } \\
\text { issues in } \\
\text { planning } \\
\mathrm{RP}, \mathrm{RD}, \mathrm{US} \\
\mathrm{MP}, \mathrm{V} \text {, } \mathrm{RE} \\
\mathrm{PO}, \mathrm{EC}, \mathrm{PQ}, \\
\mathrm{SR}, \mathrm{PS}\end{array}$ & $\begin{array}{l}\text { im portant } \\
\text { drivers } \\
\text { PF } \\
\text { RS }\end{array}$ \\
\hline & $\begin{array}{c}\text { m onitoring } \\
\text { MT }\end{array}$ & \\
\hline
\end{tabular}

\subsection{Key drivers in Iran's future political currents}

Analyzing the questionnaire, the results obtained proved the following cases as the key future drivers in Iran's political currents:

- People's demands (DP)

- $\quad$ Leadership (TL)

\subsection{Important future drivers in Iran's political currents}

Analyzing the questionnaire, the results obtained proved the Following drivers are introduced as important future drivers in Iran's political currents:

- The social-political conditions of elections time (PS)

- political competition (CS)

- Political Participation (PP)

- Political crisis (PB)

- Social capital (SC)

- Reinter state (RS)

- People's economic participation (EP)

- Foreign economic constraints (FE)

- Active participation of the political characters (PF)

- Social networks and media (MS)

\subsection{Important planning issues for Iran's political currents in future}

On the basis of the results of this study and their analysis, the following drivers are introduced as the main planning issues for Iran's political currents in future.

- Relationship between religion and politics (RP)

- National unity and coherence (US)

- Religious democracy (RD)

- Social stability (PO)

- Ethnic problem (PQ)

- Environmental conditions (EC)

- $\quad$ Social corruption (SR) 
- Resistance economy (ES)

- Interest in foreign culture (FC)

- Religious extremism (RE)

- Clever cultural approach (MP)

Various features affect the political currents in Iran and form its future changes in this domain. The critical point is to adopt proper strategies and plans to make appropriate decisions and take advantage of future opportunities for political currents. In this regard it can be stated that lack of attending to unifying elements in political system and inattention to the external and internal challenge-making and threatening factors can put the field of political movements and the future of Islamic revolution and Islamic republic of Iran system in challenge and avoid realizing the desired future in the field of political movements. The important and critical condition in this regard is attending to the principles of Islamic revolution and moving along with Islam and its authentic doctrines; otherwise and if we get far away from the revolution and its purposes, the desired future in various fields especially political movements will not be reached and the condition for the activity of political movements and groups who seek making fundamental and structural changes in all levels of Iran society is provided, it is created in the shadow of excessive attention to the leadership and people in the political system.

So it can be stated that regarding the issue under investigation which has been related to political movements in Iran, the major emphasis in this study and the applied information about political movements in Iran and its future, the point which can be mentioned is that this method can be used as a basis to investigate political movements in other societies and countries and according to it recognizing the most important powers and propellers forming the future can be reached each one of them encounters political-social life of the societies with major changes and accidents in a way.

\section{Conclusion}

One of the main areas in political sociology is the political currents and their effect in forming various social-political changes. Since knowing future issues is the main factor in adopting proper plans and strategies, this article tried to investigate the most effective factors in Iran's future political current considering futures studies. To investigate this issue, uncertainty matrix was applied. This study used a survey to ask experts' opinion about the level of importance and uncertainty of each driver. Then each driver was placed in importance-uncertainty matrix. Classifying the level of importance and effectiveness into low, average and high, the key driver scenarios, important driver scenarios, key planning issues and important planning issues for Iran's political currents were identifies. Accordingly, two important factors of transformational leadership and people's demands were considered as the key essential drivers in this area. Paying attention to or ignoring these factors by the political currents can affect their future.

\section{References}

Aghabakhshi, Ali (2000)Dictionary of Political Sciences, tehran: chapar.

Azarmand, Hamid (2006)The role of political and legal institutions in economic development, ravand, no $50-51$.

Bell, Wendell, (2003), Foundation of Futures Studies: History, Purposes, and Knowledge (Human Science for New Era), London:Transaction Publishers.

Cohen, Bruce, (1979), Introduction to Sociology, McGraw-Hill Inc.,US.

Dehkhoda, Aliakbar(2006).dictionary, Tehran: university of Tehran.

Fozi, Yahya (2009). Political Thought in Iran after the revolution, Tehran: Institute of Imam Khomeini and the Islamic Revolution

Khajesarvi, kholamreza (2003). Political competition and Political stability in Islamic Republic of Iran, Tehran: Islamic Revolution Documents Center.

Rokoie, Iman (2015). The future of political Islam in Egypt due to developments after 2011 , PhD Thesis, Iran, Imam Khomeini International University, Ghazvin.

Schwartz, P. (1996); "The Art of the Long view", New York: Doubleday. Weimer-Jehle, W. (2006); "Cross impact (CIB)", science direct, Technological forecasting \& social change, vol 73, pp334-361.

Sorosh, Abdolkarim (1991). Tehran: Publishing Serat.

Stoker Gerry, David Marsh (2010)Theory and Methods in Political Science , Palgrave Macmillan. 